\title{
A BUSCA POR CHUMBO E PRATA EM MINAS GERAIS COMO ALTERNATIVA ÀS ESGOTADAS MINAS DE OURO E DIAMANTES NO SÉCULO XIX
}

\author{
Luciano E. Faria ${ }^{a}$ e Carlos A. L. Filgueiras ${ }^{\mathrm{a}, *,(1)}$ \\ aDepartamento de Química, Universidade Federal de Minas Gerais, 31270-901 Belo Horizonte - MG, Brasil
}

Recebido em 25/06/2018; aceito em 01/10/2018; publicado na web em 31/10/2018

\begin{abstract}
THE SEARCH FOR LEAD AND SILVER IN MINAS GERAIS AS ALTERNATIVES TO THE DEPLETED GOLD AND DIAMOND MINES ALONG THE NINETEENTH CENTURY. At the turn of the nineteenth century, a frantic search took place in Minas Gerais for minerals that could prove to be of economic value and thus compensate for the decline in the production of gold and diamonds, the mainstay of the economy in the preceding century. This article addresses the search for new mineral wealth, involving the work of many different explorers and their multidisciplinary research, and particularly the unsuccessful efforts directed to finding and obtaining lead and silver in sizable amounts as two such possible replacements.
\end{abstract}

Keywords: lead and silver in Brazil; mining of galen; early analyses of minerals.

\section{INTRODUÇÃO}

Ao final do século XVIII eram evidentes os sinais de que a idade do ouro e dos diamantes, antes fartos na Capitania de Minas Gerais, já era coisa do passado. Começou-se então uma busca incessante por sucedâneos minerais que pudessem desempenhar um papel importante na economia da região. Entre esses minerais contavam-se o salitre, o chumbo, a prata e o novo metal descoberto naquela altura, o paládio. No decorrer do texto poderá ser verificado que além de considerações químicas, muitas outras, de natureza mineralógica, geológica e metalúrgica serão também introduzidas, em virtude da complexidade dos trabalhos realizados ao longo do século XIX. O desenvolvimento da pesquisa, extração e tratamento de minerais nesse período revestiu-se de uma complexidade muito maior, relativamente à exploração mineral dos séculos anteriores. Este artigo tratará dos esforços despendidos na procura de chumbo e prata, que envolveram o trabalho de garimpeiros, geólogos, mineradores, químicos, metalurgistas e vários outros profissionais. A descoberta e produção de chumbo e prata estiveram bem aquém das expectativas iniciais, que se prolongaram por todo o século XIX. Todavia, tais empenhos possibilitaram a aplicação de conhecimentos científicos os mais variados em várias das regiões desbravadas, levando a uma penetração cada vez mais ampla do território da Capitania, bem além das regiões de mineração no século XVIII, em direção à conquista e exploração do sertão.

As primeiras iniciativas tomadas para a exploração dos rios e montanhas de Minas Gerais, além da região da margem oeste do Rio São Francisco, foram feitas muitas vezes por homens oriundos das principais povoações e vilas da Capitania, ou mesmo vindos da Europa. Em 1853, o naturalista alemão Hermann Burmeister (18071892), que viajara pelo Brasil em 1850-52, disse que:

o sertão é para o brasileiro o que o 'far-west', além do Ohio, é para o norte-americano. A terra incógnita é por ele imaginada através da ignorância e considerada como deserto árido e abandonado, para o qual somente iria em caso de extrema necessidade. ${ }^{l}$

A perspicaz observação do naturalista alemão corrobora a

*e-mail: calfilgueiras@gmail.com passagem descrita anteriormente por outros dois exploradores alemães, Spix e Martius, na segunda década do século XIX, sobre o atendimento médico prestado nas proximidades de Minas Novas - no norte de MG - a um "valentão" que exigia com rispidez tratamento imediato. Em seu corpo "digno de um Aquiles", apesar das muitas feridas cicatrizadas, o que mais chamou a atenção da dupla foi o fato das várias marcas de doenças venéreas. Eles continuam sua descrição do fato indicando que:

Os nossos tropeiros explicaram o mistério, contando-nos histórias sobre diversos aventureiros, que, deserdados ou empobrecidos, ora levados pelo desespero, ora pela inclinação ao banditismo, vagam pelo sertão praticando atrocidades de toda espécie, quer a serviço de outros, quer por conta própria, e escapam ao castigo da justiça, às vezes por muito tempo, graças ao conhecimento exato da região e ao auxílio de parentes e aliados. Antes de haver no país ordem civil, eram muito numerosos esses bandidos, valentões, e amiúde instrumento de odiosos crimes, instigados pela ambição, inveja e o ciúme. ${ }^{2}$

Das longínquas paragens do oeste de Minas Gerais ou, como denominado pelos primeiros exploradores, os Sertões do Abaeté, muito pouco se conhecia até o fim do século XVIII. Enquanto na parte central e norte da Capitania a extração de ouro e diamantes já chegava à escassez quase por completa, a busca por novas fontes de renda era a motivação principal da exploração de novos recursos. Nesses locais distantes da capital, a escassez de bens devia não apenas forçar a busca por fortunas em novas regiões, mas também aumentar os conflitos existentes para os que ainda se propunham a encontrar nas minas o seu sustento. Um dos primeiros viajantes estrangeiros a narrar histórias do interior de Minas, o inglês John Mawe, de passagem pelo Tejuco em 1809, descreve que:

A poucas léguas ao norte do Rio da Prata está o riacho chamado Abaitè, celebrado por ter produzido o maior diamante em possessão do Príncipe, que foi encontrado cerca de 20 anos atrás. (...) Ao longo do perigo eles fizeram algumas tentativas no rio Abaitè, em um período em que suas águas estavam tão baixas, em consequência de uma longa estação de seca, que expunha parte de seu leito. Ali, enquanto procu- 
ravam e lavavam o leito em busca de ouro, tiveram a grande sorte de achar um diamante de aproximadamente uma onça em peso (...) A poucas léguas a partir do rio existe um consistente veio de mineral de chumbo (galena) em matriz calcária. Pude ver peças deste minério do peso de vinte libras, e é dito ser tão abundante que qualquer quantidade pode ser obtida. Alguns dos espécimes me parecem cobertos com carbonato de chumbo. O minério tem a aparência de 'minério de ceramista', e é dito que é pobre em prata. Ninguém se aventurou em trabalhar este mineral, pela dificuldade e despesas de transporte do metal para o Rio de Janeiro. Quando as vizinhanças se tornarem mais populosas, e o valor deste útil metal for melhor reconhecido, a mina irá provavelmente ser uma fonte de riquezas, por minério de chumbo é certo que é raro no Brasil, ao menos pelo que eu tenha ouvido em nenhuma outra parte se produz. ${ }^{3}$

No trecho acima, Mawe está descrevendo a descoberta do 'Diamante do Abaeté' que, de acordo com o autor, ocorreu por volta de 1789 , vinte anos antes de sua viagem por Minas. ${ }^{4}$

No entanto, os primeiros indícios de atividades científicas desenvolvidas nos arredores do rio Abaeté são encontrados apenas a partir de documento oficial datado de 19 de novembro de 1800, apontando que o Dr. José Vieira Couto "acompanhou como naturalista em serviço de sua Alteza Real, para os exames Mineralógicos", ${ }^{5}$ sendo na expedição o único cientista dentre dezenas de participantes.

\section{JOSÉ VIEIRA COUTO E PRIMEIRA DESCRIÇÃO CIENTÍFICA DOS VEIOS DE GALENA E SUAS ANÁLISES}

José Vieira Couto nasceu no Tijuco, atual Diamantina, em 1758, numa família importante da sociedade local. Couto estudou em Coimbra, formando-se em 1778 em matemática e filosofia. ${ }^{6,7}$ Após um período como lente em Coimbra, regressou ao Tijuco natal. É lá que ele, cuja fama de naturalista "era acatada na metrópole", é consultado, em março de 1797, sobre a possibilidade de se construir uma fábrica de ferro no Brasil. ${ }^{8}$ Sua resposta foi a elaboração de um longo manuscrito em 1799 intitulado "Memória sobre a Capitania de Minas Gerais, seu território, clima, e produções, metálicas: sobre a necessidade de estabelecer e animar a mineração decadente do Brasil: sobre o comércio e exportação dos metais, e interesses régios; com um apêndice sobre os diamantes e o nitro natural." Este manuscrito veio a ser publicado na Revista do Instituto Histórico e Geográfico Brasileiro em 1848. ${ }^{9}$ Dois anos depois dessa memória, Vieira Couto escreveu uma segunda memória, bastante diferente da primeira, intitulada "Memória sobre as minas da Capitania de Minas Gerais, suas descrições, ensaios e domicílio próprios; à maneira de itinerário com um apêndice sobre a nova Lorena Diamantina, sua descrição, suas produções mineralógicas, e utilidades, que deste país possam resultar ao Estado, escrito em 1801." Este manuscrito foi publicado em 1842 por Eduardo e Henrique Laemmert no Rio de Janeiro, ${ }^{10}$ e reproduzido em 1905 na Revista do Arquivo Público Mineiro. ${ }^{11}$ Nesta obra ele publicou detalhes sobre o rio São Francisco e as paisagens utilizando a Montanística da época para explicar a formação dos montes que observa na capitania, além de tudo o que observara na viagem.

José Vieira Couto se tornou o responsável pelas análises mineralógicas nesta sua incursão ao interior de Minas Gerais. Na "Memória sobre as minas da Capitania de Minas Gerais" redigida, como ele mesmo afirma, "à maneira de um itinerário", Couto descreve sua viagem desde a saída do Arraial do Tijuco até a "Nova Lorena Diamantina", uma homenagem ao influente político da época, Bernardo José Maria Lorena e Silveira, o Conde de Sarzedas, governador da Capitania.
A memória narra sua passagem pelo "Caminho do Mato dentro" no dia 04 de abril de 1800 e, dia a dia, vai indicando bens minerais que seriam de interesse à coroa no trecho que ia do arraial do Tijuco até Vila Rica. Deste ponto Couto parte em direção ao Rio São Francisco e de lá para o sertão do Abaeté. Nesta jornada, juntam-se ao naturalista o intendente do ouro de Sabará, Francisco de Paula Beltrão, que foi encarregado da arrecadação das preciosidades que aparecessem, o sargento-mor Antônio José Dias Coelho e o major Manoel Antônio de Magalhães, militares que comandavam a diligência de outros trinta soldados. Izidoro Amorim Pereira, provavelmente um dos três homens que haviam anunciado a descoberta do grande diamante do Abaeté, 4 agora como "Capitão do Regimento dos Homens Pardos" da capitania serviu de guia ao grupo. A todos eles, um conjunto entre 60 a 70 garimpeiros das vilas do entorno de Pitangui se uniram nesta exploração a partir do Rio São Francisco. Deste ponto em diante, tudo o que José Vieira Couto descreve consta da "Carta da Nova Lorena Diamantina", importante documentação cartográfica da Capitania de Minas Gerais datada de $1801^{12}$ e $1802 . .^{13}$

A ordem do governo que financiou a empreitada de Couto determinava ao grupo que fossem realizadas sondagens e extração de riquezas em novas áreas que poderiam mostrar-se plenas de diamantes e metais preciosos. Havia um desejo subjacente a essas determinações de tentar descobrir nos sertões brasileiros uma possível formação de prata que correspondesse, na porção oriental da América do Sul, à imensa formação argentífera de Potosí, no antigo Alto Peru, hoje Bolívia. Esta jazida de prata, a maior jamais encontrada no mundo, foi a mais extensa fonte de riqueza da Espanha durante mais de dois séculos, o que provocava esse ardente desejo das autoridades portuguesas em descobrir algo semelhante no Brasil, o que nunca sucedeu.

Quanto a Couto, além de identificar os veios e minerais satélites, devia ainda ser o responsável por dar indicações de serviços precisos para a correta extração e "cautelas necessárias para não haver falsidade, ou extravio" das riquezas encontradas. Diante de tudo o que foi exposto, o veredicto dos exploradores é que eles "julgarão serem aquelles territórios de riquezas, e merecimento para serem propostos tudo explorado". ${ }^{14}$ A comprovação destes fatos realizou-se com a entrega aos componentes da 'Junta da Administração e Arrecadação da Real Fazenda' de amostras de quase uma centena de diamantes que teriam encontrado naquele sertão, além de metais preciosos como platina e ouro.

A partir da visita que fez à lagoa da Piracuara, a tropa partiu em direção à Serra da Saudade, cujo pico Palhano deve ser seu ponto culminante. É a partir deste ponto que Couto afirma que em

instantes íamos a deixar terras povoadas, para nos embrenharmos em ermos desconhecidos, cujas asperezas, cujo mal sadio céo e outras cousas assim feias os nossos guias muito as amplificavam; estas idéas de mistura umas com outras, balroando o pensamento, fomentavam nos animos uma verdadeira saudade; e o nome da serra, sobre a qual caminhavamos, muito se ajustava ao estado em que então levavamos nossos corações. ${ }^{15}$

Após muitas andanças, a comitiva alcançou o Rio Abaeté e tratou de abrir imensas picadas na floresta para construção de dois pequenos vilarejos com casebres e choupanas, que denominaram Paiol Geral e Cachoeira Bonita. Estes seriam pontos de gerência de onde partiriam outras pequenas missões, o que assim se deu. Dali partiram rio abaixo para explorar e descobrir diamantes, ouro e platina nas barras dos ribeirões do Andrade e das Lágeas.

Foram quatro dias de caminhada e dez léguas acima, ora dentro d'água, mergulhados até o peito, ora fazendo trilhas pela mata até que chegaram em um ponto do córrego onde afloravam os carbonatos. 
É nesta matriz calcária de carbonato de cálcio que eles vislumbram o "veeiro de chumbo" que aflorava tanto abaixo do nível do córrego como nas suas margens. A descrição do veio de galena (sulfeto de chumbo) aponta que

Atravessa este veeiro o ribeirão em duas cintas, que eram então as que estavam descobertas, não muito separadas uma da outra, de 4 pollegadas de espessura cada uma, e cuja largura não se pode conhecer, entranhando-se pelo centro da terra. Uma cinta d'estas vai entalhada no rochedo calcareo, que é bastantemente duro, e encapada de espato branquissimo: a outra segue mais por fóra do dito rochedo, como encostada a elle, e entre uma terra vermelha, coberta de uma delgada capa tambem de espato (espato era o nome dado aos minerais de fácil clivagem, como fluorita e calcita. No caso de Couto, provavelmente ele se refere a calcitas). Em pouca distancia d'estas cintas, cavada a terra, topa-se com bastantes pedaços de minas, grandes alguns, e pezando arrobas; e estes como dispersos e isolados pela terra, cousa para admirar! e sem se encadearem e formarem veeiro; cujos pedaços são os mais puros e resplandecentes sem mistura alguma ou de terra, ou de outra qual quer pedra. ${ }^{16}$

Veeiros assim descritos especificamente para esta região foram formados por processos metalogenéticos a partir da percolação de material inferior às camadas calcárias por fluidos gerados em reservas hidrotermais, saturadas com minerais dissolvidos e ricos em metais como chumbo e zinco. ${ }^{17}$ Desta forma, os minerais metálicos podem ser formados em fissuras verticalizadas ou inclinadas dos calcários, associados a silicatos em um material quartzo-sulfetado, cuja associação de diferentes minerais, ou paragênese, normalmente envolve temperaturas elevadas. ${ }^{18}$ A geologia dos veios de galena no Sertão do Rio Abaeté é próxima daquelas mineralizações relacionadas com os depósitos de zinco e chumbo de Vazante, em Minas Gerais, atualmente o maior produtor destes metais no Brasil. Este ambiente não é comum nas eras atuais na região do Abaeté e deve ter sido formado no período pré-cambriano em que toda a porção da bacia do São Francisco jazia ao fundo de um ambiente marinho. Hoje já se descobriram depósitos marinhos recentes ou mesmo em formação "encontrados em profundidades médias da ordem de $2500 m$ e ocorrem em altas concentrações de cobre (calcopirita), zinco (esfalerita), chumbo (galena) e ainda ouro e prata". ${ }^{19}$ A região do Sertão do Abaeté, em consequência, foi fundo de mar, no período em que se originaram aquelas formações. Demais fontes minerais de galena no Brasil também derivam desta associação com rochas sedimentares, principalmente o calcário, e que hoje se encontram esgotados em cidades como Adrianópolis (PR) e Boquira (BA). ${ }^{20,21}$

No caminho de volta a Vila Rica, ainda que demonstrando fadiga e vontade de estar de volta à capital, Vieira Couto visitou outros pontos no Rio São Francisco, onde foi averiguar as informações recebidas de ribeirinhos. De acordo com estes, "se viam luzir certas pedras muito brilhantes e pesadas" que foram interpretadas in loco por Couto como sendo também galenas "de mistura com pyrites cubicas de cobre e muito miúdas" 22 (vale pontuar que o pesquisador tomara os minerais de ferro por minerais de cobre em toda a sua memória e estes mesmos deveriam ser a própria pirita ferrosa, ou sulfeto de ferro II).

Já no fim da viagem foi lavrado o "Livro de Registro dos $t r^{o:}$ (termos) de entrada no cofre de materiais obtidos da Expedição do Abaeté", datado de 10 de Junho de 1800 e disponível no Acervo de Manuscritos da Biblioteca Nacional do Rio de Janeiro. ${ }^{23}$ Este é o livro de cadastro no qual constam todas as preciosidades encontradas por aqueles que foram contratados pelo governo, além de descrever a extração de 71 diamantes. Couto também "pezou a platina, entrando nesta algumas partículas de ouro como se vê do termo deste livro dezaseis oitavas e hum quarto", um total de aproximadamente 58,5 $\mathrm{g}$ deste precioso metal. Destaca-se que ele descreve a descoberta da platina em muitos locais no mapa onde encontra "não em abastança" da mesma forma que em toda a capitania.

Sobre o chumbo e a prata, Couto afirma que

O chumbo parece abundar n'este paiz, ainda que presentemente não estejam vistas mais que duas paragens, onde elle existe. Uma d'estas é no Ribeirão da Galena, que verte para o braço do Abaité do Norte, logar já conhecido ha annos. A outra paragem fica na visinhança da Nova Lorena, ás margens do Rio de S. Francisco, duas leguas acima do Piracatú, e logo por cima da barra do pequeno Ribeirão dos Machados. Estas galenas contêm ambas ellas prata, ainda que a primeira é a mais rica d'este metal, e que fará conta a quem a trabalhar. ${ }^{24}$

Ele deu detalhes sobre as análises da galena na descrição dos minerais contidos em um cofre, provavelmente remetidos para posteriores análises. Suas calcinações eram longas (10 a 12 horas, dependendo do mineral) e as falhas nas análises constantes. Assim ele narra o mineral achado no sertão do Abaeté:

Contém esta galena chumbo, cobre, e prata. Tres quintaes de mina lançados a fundir deu o presente culote, onde pode-se distinguir muito bem o cobre do chumbo. Vem a dar por quintal de mina arriba de 98 libras de chumbo, e por quintal deste meio marco de prata. Na minha primeira remessa houve engano n'este ensaio, onde dei sómente duas onças de prata em quintal de chumbo. ${ }^{25}$

O cálculo que consta nesta nota pode dar a entender que $58,7 \mathrm{~kg}$ do minério (1 quintal) fornecem 44,5 $\mathrm{kg}$ de chumbo (98 libras), o equivalente a $87,6 \%$ de rendimento em metal. Em termos estequiométricos e levando em consideração que o processo de produção de chumbo se baseara na ustulação da galena (sua calcinação ao ar) pode-se esperar que:

$$
\begin{aligned}
\mathbf{P b S}+\mathbf{O}_{2} & \rightarrow \mathbf{P b}+\mathbf{S O}_{2} \\
239,3 \mathrm{~g} \mathrm{~mol}^{-1} & \rightarrow 207,2 \mathrm{~g} \mathrm{~mol}^{-1} \\
58.700 \mathrm{~g} & \rightarrow \mathrm{x} \quad \mathrm{x}=50.826 \mathrm{~g} \text { (massa teórica) }
\end{aligned}
$$

Há de se considerar, que, frente ao esperado teoricamente e ao que obteve, o ensaísta trabalhou com uma galena de grande pureza. Em relação à prata, que deve ter sido obtida por copelação, outro quintal de chumbo (58,7 kg de metal) produziu meio marco de prata, ou sejam, $115 \mathrm{~g}$. A proporção em prata no chumbo seria de $0,20 \%$, e no mineral $0,17 \%$. Apesar dos cálculos acima, é necessário questionar as práticas docimásticas (ou metalúrgicas) adotadas pelo naturalista, uma vez que mesmo morando em uma importante vila, a atual Diamantina, Couto não podia adquirir com facilidade equipamentos e reagentes de laboratório que o auxiliassem nas comprovações químicas que fazia para avaliar suas descobertas. ${ }^{26} \mathrm{~A}$ possibilidade de erros terem surgido nas suas análises é relevante e foi apontada por José Bonifácio de Andrada e Silva (1763-1838), que em 1806 - à época no cargo de Intendente Geral das Minas e Metais do Reino - critica José Vieira Couto, afirmando que

Do que fica exposto vê V. Ex⿱a que Jozé Vieira Couto não he Mineralogista, nem Docimasta, mas he hum Moço trabalhador e que tem zello pella commissão, de que foi encarregado; pois já com esta são quatro as remessas que tem mandado; $e$ 
ainda que em todas ellas se tem enganado na determinação dos Minerais, todavia tem sempre remetido coizas interessantes, e muitas novas, que fazem nascer os maiores dezejos aos homens da arte de vizitarem um dia tão ricas Provincias, e tão liberalm ${ }^{\text {te }}$ dotadas pela Natureza nos seus três Reino. ${ }^{27}$

Esta notificação é redigida em Coimbra e endereçada ao Visconde de Anadia, João Rodrigues de Sá e Melo (1755-1809), Secretário de Estado dos Negócios Estrangeiros e da Guerra. Bonifácio destaca ainda que nenhum dos minerais enviados de uma dita "mina de cobalto" (obra da quarta memória de Couto) seriam desse metal, mas que se tratava apenas de minerais de ferro e de grande qualidade. Isto atrai a atenção de Bonifácio, que vê um grande empreendimento no beneficiamento de ferro nas Capitanias, produto até então escasso no Brasil, e que

Nada falta pois para se aproveitarem, se não boa vontade, e providencias acertadas, sobre tudo Mestres Estrangeiros que vão encinar a nossa gente a arte de mineirar, e a de fundir e apurar os metaes. Creio que para Minas Geraes bastará $q$ vão dois Fundidores e dois Refinadores de ferro, que nas circunstancias presentes se podem mandar vir muito comodam $^{\text {te }}$ da Prussia ou Saxônia. ${ }^{28}$

É bem provável que Bonifácio já trouxesse em mente os nomes daqueles que indicaria para tal cargo, uma vez que em 1803 tinha conhecido na usina de ferro de Foz do Alge, no interior de Portugal, três alemães, um dos quais era o jovem Barão Wilhelm L. Eschwege. Como nos conta o biógrafo do Barão, Friedrich Sommer:

O ministro (D. Rodrigo Souza Coutinho) mencionou a usina de Foz D'Alge, para onde os recém-chegados deviam logo transportar-se. Como, entretanto, as perspectivas do serviço e morada naquela usina não se afiguravam muito sedutores aos olhos desses técnicos, permitiu-se Eschwege perguntar se não havia possibilidades de lhes serem os serviços aproveitados no Brasil, o que o ministro prometeu para mais tarde. ${ }^{29}$

\section{ESCHWEGE E A INSTALAÇÃO DA REAL MINA DE GALENA}

Sete anos se passaram até que, vindo de Portugal para o Brasil, o metalurgista alemão Barão Wilhelm von Eschwege demonstrasse interesse em conhecer e iniciar seu trabalho na área de metalurgia de ferro em Congonhas do Campo e naquilo que foi denominada Real Fábrica de Chumbo do Abaeté, nome como ficaria conhecido seu empreendimento nesse local. $\mathrm{O}$ aristocrata alemão é mandado a Minas depois de visitar afloramentos ferrosos na Ilha Grande em 1810, e ao chegar em Vila Rica em 1811 já demonstrava interesse em conhecer os sertões da capitania, o que o levaria a viagens como a descrita em seu livro Brasil, Novo Mundo ${ }^{30}$ No entanto, é em sua obra maior, Pluto Brasiliensis ${ }^{31}$ (publicado originalmente em 1833) e de forma mais resumida que Vieira Couto, o Barão descreve sua excursão até Abaeté e as divisas de Minas com Goiás, as quais foi encarregado de definir.

Na região as lendas sobre a tal "Serra de Metal que se diz ser chumbo" 32 aguçara sua curiosidade mesmo além-mar sobre tal jazida, da qual se falava em um depósito metálico de enormes magnitudes. O próprio Eschwege teria sido um dos responsáveis pela análise do mineral que em 1806 chegara ao Laboratório Químico de Coimbra, para que se verificasse a presença de prata. Ele descreveu no seu livro maior tais análises que foram realizadas na Casa de Fundição de Vila Rica em 1811, onde conseguiu de "um quintal de chumbo, meio marco e uma oitava de prata, que valia bem a pena ser explorada". ${ }^{33}$ Em unidades atuais, algo em torno de $236 \mathrm{~g}$ de prata por $100 \mathrm{~kg}$ de chumbo, com um rendimento de $0,24 \%$.

Em correspondências ao Conde da Barca, Antônio de Araújo de Azevedo (1754-1817) no ano de 1811, o alemão relatava que "Hontem accabei de ensaiar a dita mina ${ }^{34}$ e achei em quatro ensaios correspondentes n'hum quintal da galena $110 \mathrm{libr}$. de chumbo e no quintal de chumbo 7 onças 9 grãos ou quase $6 \$ 400$ reis de Prata", 35 o que em unidades atuais indica um rendimento de $86,0 \%$ de chumbo a partir da galena e de $0,34 \%$ de prata a partir do chumbo metálico. Eschwege ainda inventariava que com "Cinco mil cruzados são estipulados para dar princípio a abertura da Mina de Chumbo $e$ Prata do Abaeté". ${ }^{36}$

Depois de narrar a batalha humana contra a natureza na busca de maiores quantidades de amostras da galena, o engenheiro alemão repete os cálculos das proporções de chumbo e prata do mineral, agora em 1812, após construir fornos adequados para a ação em Vila Rica, ${ }^{37}$ onde fundiu em um forno de revérbero 4 arrobas de galena que renderam 2 arrobas de chumbo argentífero. Este chumbo "depois da copellação me ficarão 17 3/4 oitavas de peça em Pratta a mais fina. Esta prata mandei bem preparada ao Sr. Conde d'Aguiar, $p^{a}$ ser levada a presensa de $S$. A. R." ${ }^{38}$ Destes dados supõe-se um rendimento de obtenção de chumbo a partir de minério de $50 \%$ e de um rendimento de prata a partir de chumbo de $0,22 \%$.

O Conde de Aguiar acima descrito era o Vice-rei do Brasil, Fernando José de Portugal e Castro (1752-1817), que recebeu das mãos do então governador da Província de Minas Gerais Francisco de Assis Mascarenhas, o Conde da Palma, uma barra de prata produzida por Eschwege a partir da galena argentífera de Abaeté (Figura 1) cuja massa, 59,44 g, tem valor muito próximo às " $1733 / 4$ oitavas" de massa de prata obtida, equivalente a $63,6 \mathrm{~g}$.

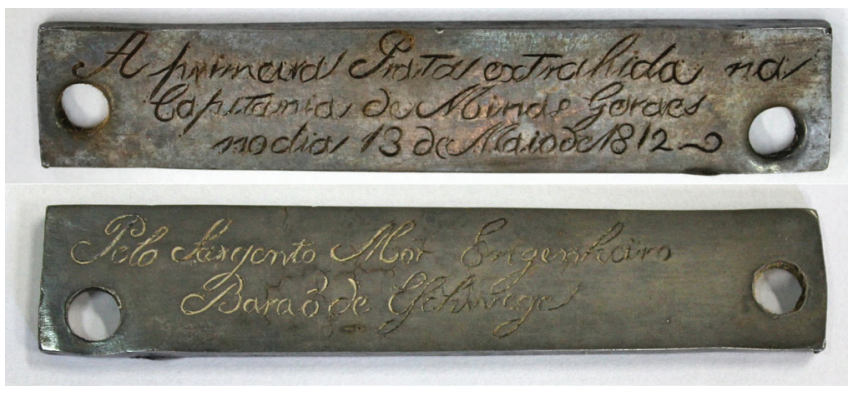

Figura 1. Frente e verso de um lingote de prata onde se lê "A primeira Prata extrahida na Capitania de Minas Geraes no dia 18 de maio de 1812. Pelo Sargento Mor Engenheiro Barão de Eschwege”. Imagem obtida no Museu Histórico Nacional do Rio de Janeiro (dimensões $93 \times 18 \times 3 \mathrm{~mm}$; massa equivalente a $59,44 \mathrm{~g}$ )

Seguindo com sua descrição sobre o veeiro de galena no Pluto Brasiliensis, Eschwege indica que para o processo de extração necessário em leitos carbonáticos, alguns escravos que levara para Abaeté em sua segunda viagem de 1813 deveriam aprender o uso de explosivos..$^{39}$ Isso ocorreu após os mineradores terem retirado a galena que estava exposta ao fluxo do rio que dessa forma teria erodido e corroído o calcário em torno do veio, facilitando sua retirada inicial. Ele ainda indica que até aquele ano já se teriam obtido 400 centner (o equivalente a 10,5 toneladas) que "fundida e reduzida a dinheiro, teria compensado perfeitamente as despesas feitas". ${ }^{40}$

Nos dois anos que se seguiram desde a chegada até a mina, Eschwege tentava aumentar sua força de trabalho técnica no empreendimento, fazendo requisição à Coroa de mais europeus aptos a obter o chumbo e copelar este metal para obtenção da prata. Em 1815 ele se queixa de ainda não ter tido sucesso na mina por causa 
dos "poucos escravos velhos que alli estão trabalhando, ainda fiz mais que esperava, e não he pequena cousa n'hum inculto Certão", além da ausência do mestre mineiro que "por muitas vezes pedi a S. A. muitos annos antes da sahida do Mestre Alemão que lá estava empregado, e a quem se ficou devendo quinhentos mil reis". ${ }^{41}$

Outras dificuldades oferecidas pela natureza ou mesmo de ordem financeira fizeram com que o empreendimento até 1821, data do regresso de Eschwege à Europa, não retornasse os investimentos feitos. No entanto, toda sua obra, de acordo com o próprio autor, fora sincera e não aumentava ou diminuía o potencial da fonte do minério que identificava, ao contrário do fato comum de alguns governantes que magnificavam ou reduziam a importância de bens naturais de acordo com relatórios que lhes eram enviados. Ele se diz vítima do governo por tentar ser sincero em seus registros. As dificuldades de uma fábrica em tão distante sertão inviabilizavam a produção, a distribuição (nas péssimas estradas e ausência de rios navegáveis) e principalmente a venda do chumbo - que nem mesmo poderia competir em preço com o chumbo europeu no mercado de parte da capitania.

\section{JOÃO MONLEVADE E A OBTENÇÃO DE CHUMBO E PRATA EM GRANDE ESCALA}

O francês Jean-Antoine Felix Dissandes de Monlevade (17891872) que é citado por Eschwege no Pluto Brasiliensis como seu sucessor no empreendimento do Abaeté ${ }^{42}$ era formado na École Polytechnique de Paris e em 1812 se diplomara no curso de Engenharia Metalúrgica. ${ }^{43,44}$ Graças ao seu talento, foi incorporado ao Corpo de Engenheiros Militares e em 1817 encarregado de missões oficiais no Brasil pelo governo português.

Monlevade foi um dos mais importantes industriais franceses a atuar no Brasil imperial, com grande conhecimento em mineralogia e metalurgia e que, mesmo antes do capítulo de Abaeté, já começava a montar seu empreendimento no ano de sua chegada ao distrito que hoje é uma cidade que leva seu nome (João Monlevade), montando um negócio que foi o gérmen da siderúrgica Belgo-Mineira, atual ArcelorMittal. Enquanto montava este empreendimento, Monlevade prestou serviços ao governo da província, analisando minerais e metais de diversas minas e distritos. ${ }^{45}$

É provável que um de seus primeiros empreendimentos tenha sido a mina do Abaeté onde teria encontrado a galena beneficiada por Eschwege. Monlevade parece não ter deixado, como os ilustres antecessores, nenhuma memória, livro ou tratado descritivo sobre as minas ou o chumbo do Abaeté e suas regiões, por estar "prestando favores" à Junta do governo provincial de Minas, situado na agora Cidade Imperial de Ouro Preto. Tais "favores" podem ser lidos na correspondência enviada a José Bonifácio pelo Presidente da Província e Visconde de Caeté, José Teixeira da Fonseca Vasconcelos, entre o período de 1824 a 1826 , e demais personagens:

Ill. ${ }^{\text {mo }}$ e Ex. ${ }^{\text {mo }}$ Snr.' - A galena do Abaeté requissima em intenção, e extensão, como fui informado pelo Barão d'Esch Wege e por outras pessoas de credito, pode interessar muito pelo fornecimento do chumbo, e de algu'a prata. Athe aqui por falta de metallurgicos praticos, nada se tem obtido, posto que o Governo tenha feito não pequenos sacrifícios. Rezide no Termo da Villa de Caethe M. ${ }^{r}$ de Monlevade sábio Mineralogico, e que já trabalhou muitos annos em minas similhantes na França. Este Homem amigo do Brazil, como se fosse um indigena, me tem dito de bom grado se prestaria a hir ensinar a construção de fornos, e o modo de se fundirem os mineraes, e de se separar a prata do chumbo. Portanto se V. Ex. ${ }^{a}$ encarregar o sobredito Monlevade desta delligencia, julgo que verá os rezultados que ainda se não poderão obter de outras mãos. Talvez a creação de hu'a Companhia, seja o meio mais adequado de se emprehenderem em grande estes trabalhos, para o que, e mesmo para cooperar com, lembro a V. Ex. ${ }^{a} o$ generozo Patriotismo do Cap. ${ }^{\text {mor }}$ e G. M. ${ }^{r}$ Geral João Baptista Ferr. $^{a}$ de Souza Coutinho em que já falei a V. Ex. ${ }^{a}$, e a quem pode o Governo Provincial commetter a direção total deste negocio cujo sucesso então presseguro a V. Ex. ${ }^{a} D .{ }^{s} G$. a V. Ex. ${ }^{a}$ Rio de Janr. ${ }^{o} 16$ de Maio de 1823 - Ill. ${ }^{\text {mo }}$ e Ex. ${ }^{\text {mo }}$ Snr' Joze Bonifacio de Andrada e Silva. - Antonio Gonçalves Gomide. ${ }^{46}$

Em cartas que seguem anexas ao texto acima, João Batista Ferreira de Souza Coutinho, o Capitão Mor, tinha-se inteligenciado que o francês se prontificara a analisar a prata e o chumbo contidos no minério, mas que antes de quaisquer apreciações analíticas preferia realizar Inspeção ocular em visita à mina em Abaeté.

Monlevade manifestou oficialmente em algumas cartas e ofícios seus encaminhamentos de custos e pagamentos necessários para tal obra, além de manter constante correspondência com um periodista da cidade de Ouro Preto. Em um dos primeiros cálculos da riqueza do sertão, Monlevade revelou ainda detalhes do processo e das proporções utilizadas na obtenção dos metais chumbo e prata em artigo publicado no jornal ouro-pretano "Abelha do Itacolumy”, em 1824:

Cento e cincoenta oitavas de Galena quasi pura me forão remettidas pelo Ill ${ }^{\text {mo }}$ Guarda Mor Geral João Baptista Ferreira de Souza Coutinho. Ella foi reduzida a pó, e ustulada para volatilisar o enxofre unido ao xumbo; depois foi misturada com meia oitava de limalha de ferro, e posta em um cadinho brasqueado. ${ }^{47}$ Este cadinho foi tampado exposto meia hora a hum fogo ordinário de forja; depois de esfriar achou-se dentro 83 oitavas de xumbo metallico muito puro, e humas fezes compostas principalmente de sulfato de ferro. Trez oitavas deste xumbo passadas na copella derão um botão de Prata, que pezou 2 réis 13-256. Pelo calculo ve-se que 100 libras deste mesmo xumbo há de dar pouco mais de sete oitavas de pezo de Prata. Em resultado de duas experiências, que fiz antes com outros pedaços da mesma mina, achei 11 a 12 oitavas de prata para cada 100 libras. Ve-se primeiro que 100 partes de Galena dão 60 de xumbo: $2 .^{\circ}$ que 100 libras deste xumbo dão de huma onça a onça e meia de Prata, a qual contem provavelmente Ouro; mas que não posso conhecer por não ter a minha disposição acido-nitrico privado de acido-muriatico. ${ }^{48}$

Além de identificar a possível existência de mais um elemento em sua análise, o ouro, Monlevade repete a análise de obtenção de chumbo a partir de galena com rendimento de $64 \%$ de chumbo a partir do minério. Aqui ele detalha o que pode diferenciar dos ensaístas anteriores - Vieira Couto e Eschwege - pois faz questão de narrar a etapa de purificação do "xumbo" pela adição de limalhas de ferro que retirariam os resíduos de enxofre do mineral que ainda não havia reagido. $\mathrm{O}$ teor de prata, por outro lado, não confere com o que aponta uma de suas primeiras correspondências oficiais a respeito da extração do chumbo e da prata da mina do sertão, que aparece reescrita no Revista do Arquivo Público Mineiro de 1898, intitulada "Chumbo e prata do Abaetê": 49

... eu já tive a honra em hua nota sobre a $d^{a}$ mina de Informar a V. Ex. ${ }^{a}$ q.' eu tinha derretido 703 arrobas de chumbo em barras procedidas de 1200 ar. de Galena pura, q.' o fillão dava esperanças fundadas de inserar abundante mineral, $o$ Inventario anexo dava a $V$. Ex. ${ }^{a}$ hua ideia exacta do estado deste estabelecim ${ }^{\text {to }}$. Restava p. $^{\text {qa }}$ cumprir com os desejos de V. Ex. ${ }^{a}$ apurar a prata. A falta de aparelhos, e agentes ne- 
cessários não me permittirão concluir de todo este trabalho, porem tenho a satisfação de apresentar a V. Ex. ${ }^{a} 2$ lib 1/2 oit e 36 grãos de prata fina procedidos de 50 arrobas de chumbo. Esta experiência feita em ponto já grande, vem a dar 2 onças 1/2 1/8 p.r 100 lib de chumbo; e confirma os ensaios da capellação, que enviei a V. Ex. ${ }^{a}$, e mostra que a Galena do Abaité tem em prata hua riqueza superior às da Europa, $e$ merece não só por este motivo, como pela posição favorável da mina, e a qualid. ${ }^{e}$ do chumbo a maior contemplação ${ }^{50}$

A carta dá a entender que Monlevade tinha-se encarregado de "fundir" a galena de Abaeté. No entanto ele mesmo não realizou os testes de copelação do metal em sua análise de conteúdo de prata, conforme consta do "Inventário anexo". Este material anexado à carta parece descrever a análise feita por outro estrangeiro, o alemão Andreas Augustin (ou André Augustino) que ensaiou as proporções argentíferas no metal. Da nota anteriormente transcrita podemos mais uma vez observar as análises quantitativas de acordo com as proporções de 1.200 arrobas $(17.640 \mathrm{~kg}$ ) de galena foram obtidas 703 arrobas $(10.334 \mathrm{~kg}$ ou 10 toneladas com rendimento de $67,6 \%$ de chumbo a partir do minério). Deste chumbo, de cada $100 \mathrm{lb}$ (ou 100 libras, o equivalente a 45.360 g) o total em prata obtido seria de 7,65 g de prata, com rendimento, a partir do chumbo, de $0,17 \%$. A nota é ainda confirmada por notícia divulgada no jornal "O Universal", no. 3, de 19 de Abril de 1828 que, narrando os feitos de Monlevade, afirma que o mesmo "foi às Minas do Abaithé, apurou, e remetteu mais de 600 arrobas de chumbo, e delas extrahio nesta Cidade huma porção finissima de prata, que se apresentará no Rio de Janeiro pelo Ex. ${ }^{\text {mo }}$ Sr. Visconde de Caethê" ${ }^{51} \mathrm{Um}$ aspecto surpreendente para leitores modernos é a enorme quantidade de material transportado do Abaeté a Ouro Preto, distante de cerca de $500 \mathrm{~km}$. Este transporte era normalmente feito em lombo de burros, o que mostra a dificuldade do empreendimento.

Dois pontos chamam atenção nestes documentos: o primeiro é que todo o chumbo que Monlevade obtivera em Abaeté fora obtido no processo de ustulação, e gerou um número entre 600 a 700 arrobas de metal (algo em torno de 10 toneladas de chumbo ou em torno de $1 \mathrm{~m}^{3}$ ); o segundo ponto interessante é que toda esta massa e volume de chumbo teriam sido transportados por $500 \mathrm{~km}$, como assinalado acima, até ser quase completamente copelado (em uma reação em que o chumbo se oxida ao ar na formação de $\mathrm{PbO}$ e parte deste óxido se volatiliza e se perde do forno) para a produção da prata por mais de 2 meses de trabalho. Isso com certeza exigiu grandes problemas logísticos e elevados gastos energéticos, além de ter lançado na atmosfera de Ouro Preto enormes quantidades de um metal pesado que pode estar ligado a diversos males à saúde. Outro documento assinado por Monlevade, de 09 de maio de 1826, dava respostas às imensas proporções envolvidas no processo de beneficiamento do chumbo que deve ter sido custeado pela Junta da Fazenda de Minas Gerais e despachado pelo almoxarife Joaquim José Theodoro:

Será precizo Ill ${ }^{\text {mo }}$ Sen $r$ Sargento Mor Joaquim Theodoro para a copellação do jumbo restante, mandar vir 200 burros de lenha boa, ou o equivalente; (ilegível) 200 burros de carvão e 6 carros de ossos. ${ }^{52}$

Monlevade novamente explicita em uma "nota abreviada" e datada de 07 de Abril de 1825 como converteu a galena em chumbo e dá ideia do volume deste metal gerado na "Mina, mais rica pela sua forma, do que pelos seus productos" em que reafirma a quantidade de galena extraída e a obtenção de 703 arrobas de chumbo em barras..$^{52}$ Destas, 212 continuavam na Imperial Mina da Galena, somando uma massa total de 394 arrobas e 20 libras, à data de 08 de Agosto de 1825. É desconhecido se tal proporção de chumbo tenha vindo até Ouro Preto para ser copelada, mas o mesmo inventário feito por Monlevade ainda descreve uma série de itens que lá ficaram sob guarda do soldado Justino Pacheco.

Todavia, apesar de muitos itens descritos por Monlevade constarem como "arruinados", em Sessão em 21 de Julho de 1835 (sob presidência do Sr. Araujo Lima) da Assembleia dos Deputados do Império, Aristides André Mornay propõe ao governo da Província de Minas a compra do empreendimento minerário de Abaeté, que ainda pertencia à Fazenda Nacional, na esperança de se obter "uns tantos por cento sobre os productos que se extrahirem da mesma mina". ${ }^{53}$ Mesmo assim demonstra-se o interesse continuado do potencial do veeiro como provedor de um "thezouro da natureza, que ainda compramos do estrangeiro".

A nota se converte em lei quando a Assembleia reunida resolve autorizar o governo, não a extrair, mas sim a estimular companhias de exploração mineral, designando obrigações e vantagens a estas. Esta seria uma das últimas menções sobre a Real/Imperial Fábrica, até que, no fim do século XIX, novos estudos de alunos da Escola de Minas de Ouro Preto - fundada em 1876 por Dom Pedro II e dirigida por Henri Gorceix - voltassem a dar destaque à galena argentífera.

\section{A TENTATIVA DA INSTALAÇÃO DE UMA METALURGIA MODERNA POR UM EX-ALUNO DA ESCOLA DE MINAS DE OURO PRETO: FRANCISCO DE PAULA OLIVEIRA}

É assim que um dos ilustres alunos da Escola de Minas tem contato com a galena do Abaeté. Francisco de Paula Oliveira, que consta da lista dos primeiros egressos da Escola como Engenheiros de Minas $^{54}$ viria mais uma vez tentar implementar a metalurgia na região do Abaeté, hoje marcadamente localizada dentro das divisas do município de Patos de Minas, no oeste mineiro.

Oliveira foi um dos primeiros alunos da escola (entrada em 1876 e formatura em 1878), diretamente beneficiado por Gorceix, que pediu alteração de seu próprio salário para que o corte de custos da recém-inaugurada Escola pudesse conceder a Oliveira e a outros dois estudantes uma bolsa e a oportunidade de cursar engenharia. ${ }^{55}$

Mais tarde Oliveira ainda seria denominado por Gorceix de "ativo defensor da geologia econômica" ${ }^{55}$ o que representa bem o lema da Escola: cum mente et malleo, ou seja, "com a mente e o martelo" em uma proposta clara de pôr em prática o conhecimento teórico adquirido. Depois de ter participado da Comissão Geográfica e Geológica de São Paulo (CGGSP) fundada em 1886 e após publicar diversos artigos nos Annaes da Escola de Ouro Preto, Oliveira teria sido ainda apontado em 1896 como "um dos primeiros geólogos do Brasil, discípulo e braço direito de Gorceix" e assim sondado para assumir como lente da Escola Politécnica de São Paulo, fundada em 1893, onde "preencheria com toda proficiência a cadeira de mineralogia e geologia" ${ }^{56}$ Neste mesmo ano ele é apontado como o diretor da seção de Geologia do Museu Nacional do Rio de Janeiro. ${ }^{57}$

Em 1881, Oliveira publicou num longo artigo no primeiro número dos Annaes da Escola de Minas de Ouro Preto o trabalho que tinha feito em 1879 intitulando-o "Exploração das minas de Galena do Ribeirão do Chumbo affluente do Abaeté e estudo da zona percorrida de Ouro Preto até esse logar". Seu objetivo seria o de "fazer conhecidos estes veieiros e a sua riqueza (...) estudando, de passagem, a geologia dos terrenos percorridos" ${ }^{58}$ Neste trabalho ele analisava as formações geológicas entre Ouro Preto e Pitangui, e a partir desta cidade até a referida mina.

Quando atravessa o rio Areado, já afirma Oliveira que "se pisa na matta denominada do Chumbo, que faz parte da fazenda pertencente ao governo geral" até que chega na povoação onde afloram os calcários, ora no meio da mata, ora próximos ao ribeirão do Chumbo. Ainda na parte descritiva do seu trabalho, deixou registrados os 
estudos orográficos (referentes a descrição e análise de montanhas) em que associou formações geológicas a "grupos" de montanhas, da mesma forma que na classificação moderna, além da hidrografia dos principais rios por onde passava.

A descrição que continua a fazer, após encontrar seu ponto de interesse, a mina de galena, é narrada com constantes referências aos textos de Eschwege e muito pouco ou quase nada do que teria deixado Monlevade. Sua descrição mineralógica ainda conta com análises físico-químicas dos minerais que descreve associados às formações geológicas que encontra e aqui ele corrige as observações do " $D r$. Couto", ou mesmo as impressões da "voz geral entre os habitantes dos arredores do Indaiá", ${ }^{58}$ que apontavam que o argilito verde (tipo de rocha formada da compactação da argila) da serra do Capacete seria de minério de cobre.

$\mathrm{Na}$ descrição que fez a respeito dos calcários da região do rio Abaeté, Oliveira reconhece a galena argentífera dentre outros veeiros cristalinos de calcita $\left(\mathrm{CaCO}_{3}\right.$, que ele denomina carbonato de cal). Estes calcários ainda "prestam-se ao fabrico de uma cal muito boa para construções", assim como poderiam ser utilizados para a fábrica de chumbo os "grés vermelhos que teriam utilidade na construção dos fornos a revérbero ou à cuve no tratamento da galena". ${ }^{58}$

No sítio, Oliveira encontrou a mina abandonada há muitos anos e, dessa forma, chuvas seguidas e cheias do ribeirão recobriram de terra todo o veeiro e a cava subterrânea, de modo que teve que se esforçar muito para poder ter acesso à galena e dela "extrahir algumas arrobas". São na verdade, de acordo com Oliveira, dois veeiros com variações entre 5 e $8 \mathrm{~cm}$ de espessura diretamente encravados em camadas paralelas no calcário, separadas um do outro por uma camada de $10 \mathrm{~cm}$ desse carbonato.

Em um ponto da mina Oliveira extraiu mais de uma arroba de galena pura - ora da terra ou explodindo a rocha matriz com pólvora - que estavam "rodeados de sílica em cristais" ou provavelmente, cristais de quartzo (Figura 2). A extração que continuou fazendo dependia ainda do bombeamento de água derivada tanto do córrego que passava ao largo quanto de uma nascente interna que, minando água aos poucos, ia cobrindo a rocha de um lado e do outro do córrego. Aqui ele se mostra convicto do processo de metalogênese dos depósitos, conforme entendimento atual já descrito, ao afirmar que aquelas frestas preenchidas entre os calcários deveriam ter sido "verdadeira chaminé por onde passariam os vapores de galena e de blenda". Oliveira ainda observou que, de acordo com Eschwege, o potencial do veeiro aumentava à proporção que se aprofundava, contudo, a falta de broqueadores (equipamentos de perfuração para inclusão de explosivos na rocha matriz) e de máquinas para bombear água não lhe permitia maiores avanços.

Ao terminar sua descrição da mina e de sua forma de extrair a galena, Francisco de Paula Oliveira indica os resultados da análise do mineral extraído em diversos pontos de suas cavas (Tabela 1) mas não dá detalhes sobre a técnica de ensaio e aponta apenas que os mesmos foram realizados no Laboratório Químico da Escola de Minas de Ouro Preto.

Em termos de aspectos físicos e de suas intrusões estão presentes na amostra cristais de quartzo, carbonato de cobre [provavelmente a azurita $-\mathrm{Cu}_{3}\left(\mathrm{CO}_{3}\right)_{2}(\mathrm{OH})_{2}$ ] e vauquelinita (mineral de composição mista de fosfatos e cromatos de cobre e chumbo), que assim deveriam fazer parte da ganga do minério. Sobre as proporções de chumbo e prata que analisou daquilo que extraiu em dois pontos extremos da mina ao norte a ao sul da cava, mais ainda de amostras que coletara no antigo forno onde achou restos de chumbo reduzido.

Sobre o teor em prata, apesar de ser o ensaísta que encontrou a menor proporção comparado com Vieira Couto, Eschwege e Monlevade, Oliveira concluiu que esta seria uma "riqueza já bastante considerável para dar logar a uma exploração vantajosa". O restante de todo seu artigo (outras 5 ou 6 páginas seguintes) dá apontamentos de como desviar a água do córrego para que o mesmo não interferisse na dinâmica hídrica da mina, além de indicações para um grande empreendimento metalúrgico com vistas tanto à extração quanto ao beneficiamento em fornos da galena e de seus rendimentos anuais.

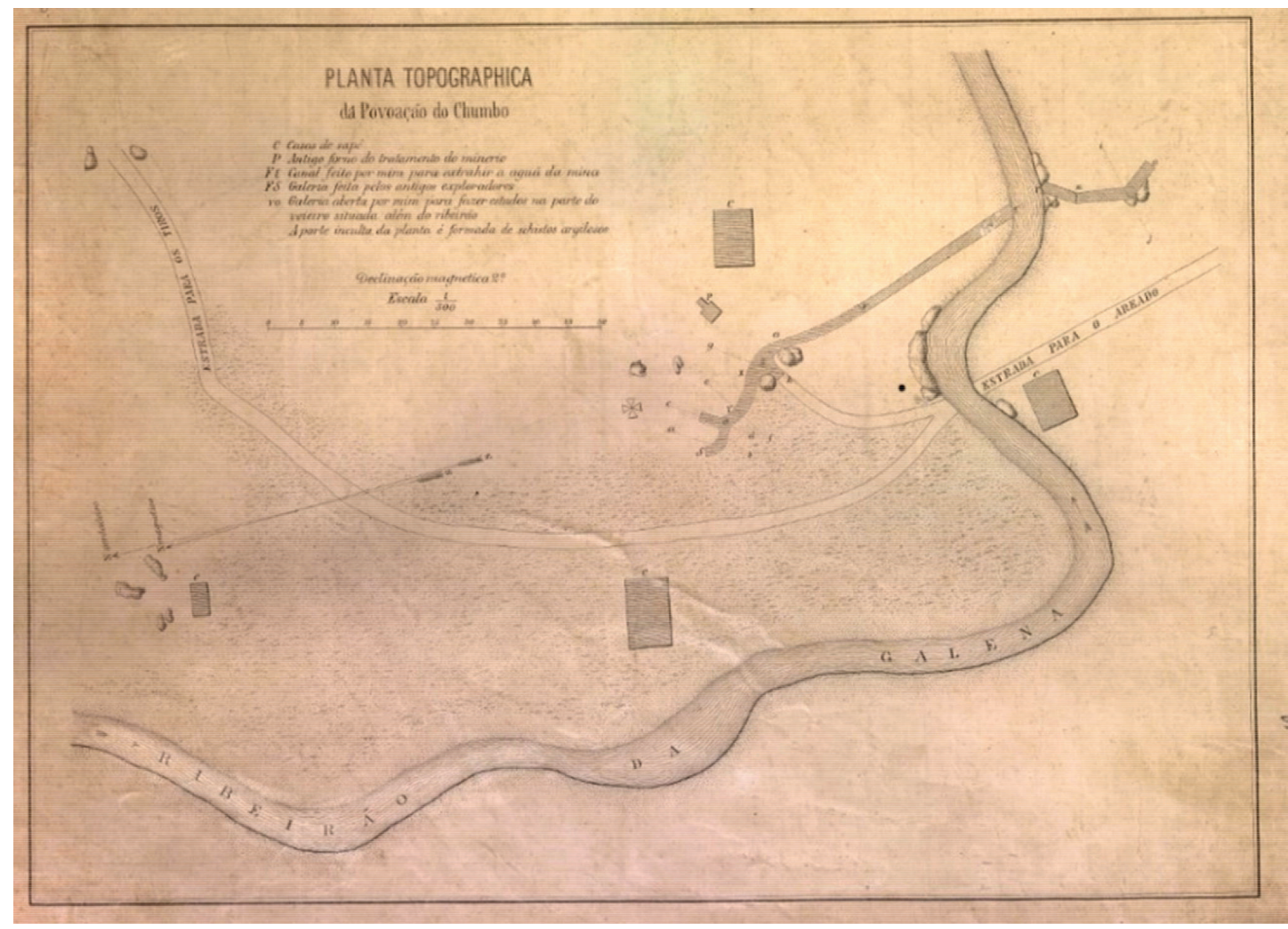

Figura 2. Planta das cavas superficiais e subterrânea da Mina de Galena ${ }^{59}$ 
Tabela 1. comparação entre os valores de metais obtidos nas análises de F. de Paula Oliveira

\begin{tabular}{lccc}
\hline & $\begin{array}{c}\text { Massa ensaiada } \\
(\mathrm{g})\end{array}$ & $\begin{array}{c}\text { Teor de Pb em } \\
\text { galena }(\%)\end{array}$ & $\begin{array}{c}\text { Teor de Ag em } \\
\text { chumbo }(\%)\end{array}$ \\
\hline Ponto 1 & 20 & 40 & 0,149 \\
Ponto 2 & 20 & 60 & 0,150 \\
Antigo forno & 30 & - & 0,142 \\
\hline
\end{tabular}

Sua bela conclusão dos diversos assuntos tratados é delineada da seguinte forma:

Que a minha fraca voz seja ouvida por alguém mais hábil e poderoso, que o Sr. Dr. Martinho Contagem (político de $\mathrm{MG}$ ), o Exm. Sr. Barão do Indaiá e outros que muito podem neste sertão, se convençam das riquezas que nelle existem e contribuam energicamente para sua prosperidade, é o que sinceramente espero. ${ }^{60}$
Oliveira aceitaria em 1881 ser sócio de outro ex-aluno da Escola de Minas de Ouro Preto, Chrispiniano Tavares, e juntos recebem empréstimos promulgados pela Assembleia Legislativa de Minas Gerais em uma quantia de 40:000\$000 réis, a serem pagos após 27 anos com juros de $7 \% .{ }^{61}$ Enfim, não fica ainda óbvio para este estudo - e também foge do nosso escopo principal - qual teria sido o destino das verbas públicas e privadas que os dois sócios conseguiriam para a exploração mineral em Abaeté, pois em 1883 Tavares aparece como responsável por uma mineração de chumbo em Goiás - na Companhia de Mineração Goyana ${ }^{62}$ - enquanto Gorceix um ano antes, em comunicação postal com o Imperador D. Pedro II, referira-se a uma forja Catalã implantada por F. P. Oliveira em Abaeté, onde " $f e z$ ferro de boa qualidade". ${ }^{6 .}$

\section{SITUAÇÃO ATUAL DA MINA DE GALENA DO ABAETÉ}

Atualmente, a localização geográfica correta para todas as informações descritas pelos naturalistas e mineralogistas estudados é que a Mina da Galena se situe no município de Patos de Minas (Figura 3).

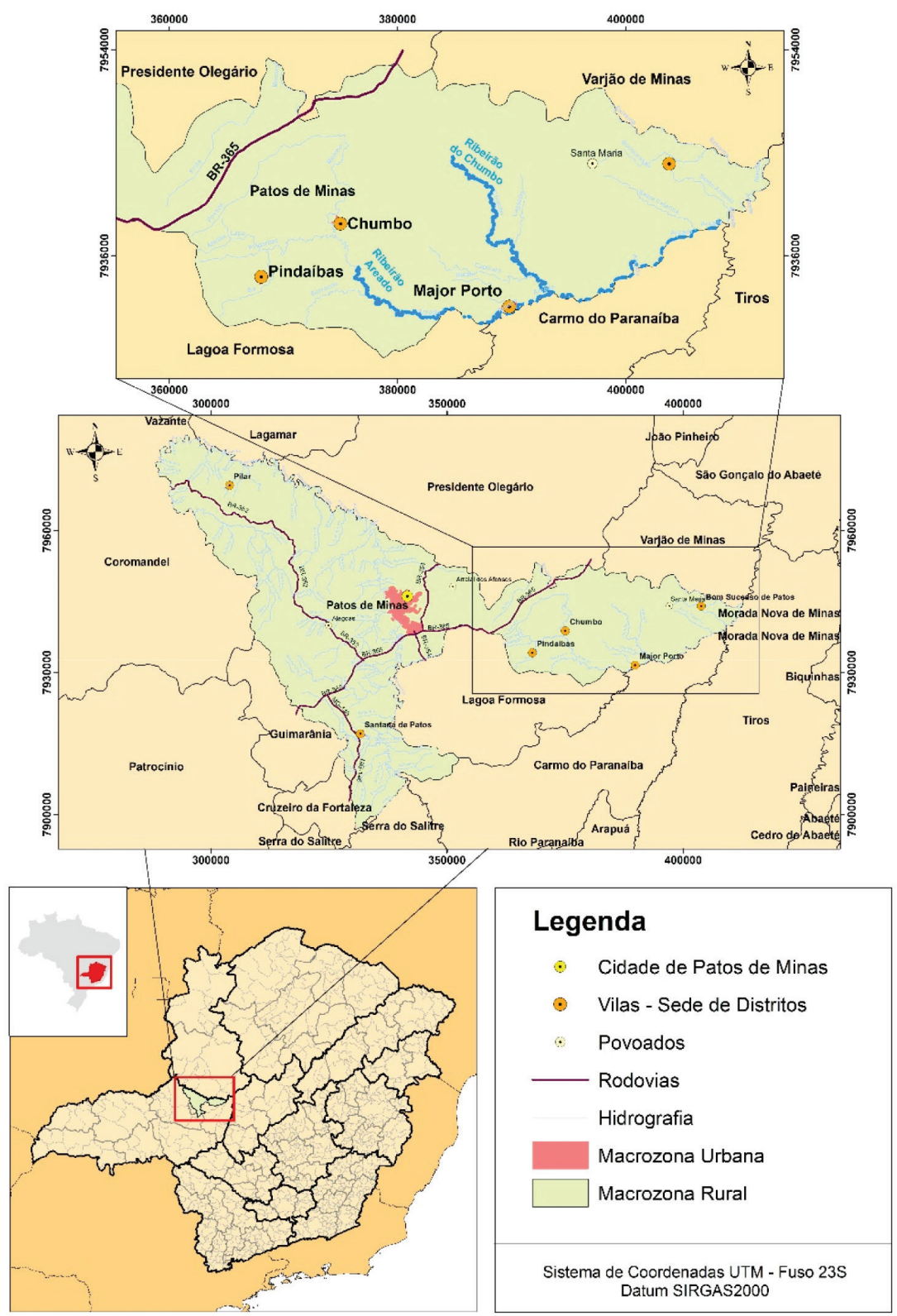

Figura 3. Localização atual dos povoados do Chumbo, Major Porto (antiga Areado) e Pindaíbas do município de Patos de Minas, MG 
O mapa atual da cidade traz até hoje como nome de um de seus povoados o "Chumbo" que tanto marcou a história desta região da bacia hidrográfica do Rio Abaeté. O detalhe da Figura 3 mostra ainda o distrito de Major Porto que está às margens do Ribeirão Areado, próximo às confluências do Ribeirão do Chumbo.

As visitas de campo feitas para este trabalho mostraram que as toponímias da região são muito diferentes daquelas dos estudos históricos, mesmo algumas recentes. O ribeirão da Galena hoje é denominado Ribeirão do Chumbo (aqui também se destaca que ao norte deste mesmo ribeirão existe o distrito da cidade vizinha, Presidente Olegário, denominado Galena) e muito pouco se sabe, na localidade o porquê deste nome. Os moradores locais afirmam que o nome se deve ao fato de os antigos habitantes terem sido vilões e pessoas de má índole que tratavam seus negócios à bala ou ao chumbo destes projéteis, além de afirmarem ter existido no passado um antigo distrito de chumbo destruído por enchentes.

Apesar de tudo, foi possível ainda a localização exata do ponto onde devem ter ocorrido as extrações sequenciais do minério de chumbo e prata pois, ao se percorrer o ribeirão do Chumbo, os calcários realmente só afloram em um único ponto que concorda com as descrições de todos que por lá passaram: lapas e lajes de rocha, esculpidos pelo córrego, se lançam sobre as águas, dando até mesmo abrigo a pessoas e animais. O formato do rio neste ponto (Figura 4) também é único e, somado a tudo isso, o relato do responsável pela fazenda diz ai ter havido no passado enorme utilização de mão de obra escrava, e que muitos deles tiravam pequenas amostras de uma pedra branca a qual, sob aquecimento, gerava o chumbo que utilizavam em instrumentos de pesca.

Entretanto, é uma infelicidade que nenhum vestígio arqueológico aparente indique que ali floresceu um dos primeiros empreendimentos minerários do sertão de Minas Gerais, pois o desconhecimento da riqueza histórica e da importância do local fez com que os proprietários demolissem casas que, de acordo com os mesmos, foram senzalas e casas de ex-escravos. Outros possíveis vestígios de fornos de fundição, cavas subterrâneas e furos de prospecção foram preenchidos por terra para evitar que o gado caísse e se ferisse em acidentes que ocorriam constantemente no local. Já nas margens do córrego pode-se evidenciar uma grande quantidade de blocos quebrados e cominuídos de calcário, mas sem sinal aparente do mineral denso e cinza de chumbo, a galena. Por outro lado, existem ainda alguns vestígios da forja catalã e fornos de aço que Francisco de Paula Oliveira estabeleceu a alguns quilômetros desse ponto e no local, além de algumas pedras que foram usadas como refratárias e de minério tratado e reduzido, pode ser encontrada a cabeça de martelo da forja que foi utilizada para tratar e moldar o aço no interior de Minas. O fim do século XIX marcou o encerramento de quaisquer atividades de busca de galena, chumbo ou prata naquela região.

\section{ANÁlises de AMOSTRAS DA GALENA DO ABAETÉ FEITAS NO SÉCULO XIX E SUA COMPARAÇÃO COM ANÁLISES CONTEMPORÂNEAS}

É interessante analisar o avanço das metodologias de análises químicas feitas por cada um dos quatro pesquisadores mencionados, José Vieira Couto, Barão de Eschwege, Jean Monlevade e Francisco de Paula Oliveira, referentes à extração de chumbo da galena e depois da prata proveniente do chumbo, conforme mostra a Tabela 2.

Nota-se que o resultado bem acima da média para o teor de chumbo obtido por Couto ( $88 \%$ ) deve ter sido um dos motivos pelo interesse inicial na extração e beneficiamento da galena em ponto tão distante de qualquer centro comercial da capitania de Minas Gerais.

Tabela 2. comparação entre os valores de metais obtidos por Vieira Couto, Eschwege, Monlevade e F. de P. Oliveira

\begin{tabular}{lcccc}
\hline & Ensaio & Técnica usada & $\begin{array}{c}\text { Teor de Pb } \\
\text { na galena } \\
(\%)\end{array}$ & $\begin{array}{c}\text { Teor de Ag } \\
\text { no chumbo } \\
(\%)\end{array}$ \\
\hline Vieira Couto & $1^{\text {o }}$ & calcinação & 88 & 0,20 \\
\hline Eschwege & $1^{\circ}$ & calcinação/copelação & - & 0,24 \\
& $2^{\circ}$ & calcinação/copelação & 86 & 0,34 \\
Monlevade & $3^{\circ}$ & calcinação/copelação & 50 & 0,22 \\
\hline Oliveira & $1^{\circ}$ & calcinação/copelação & 60 & 0,06 \\
\hline MÉDIA & $1^{\circ}$ & calcinação/copelação & 67 & 0,17 \\
\hline
\end{tabular}
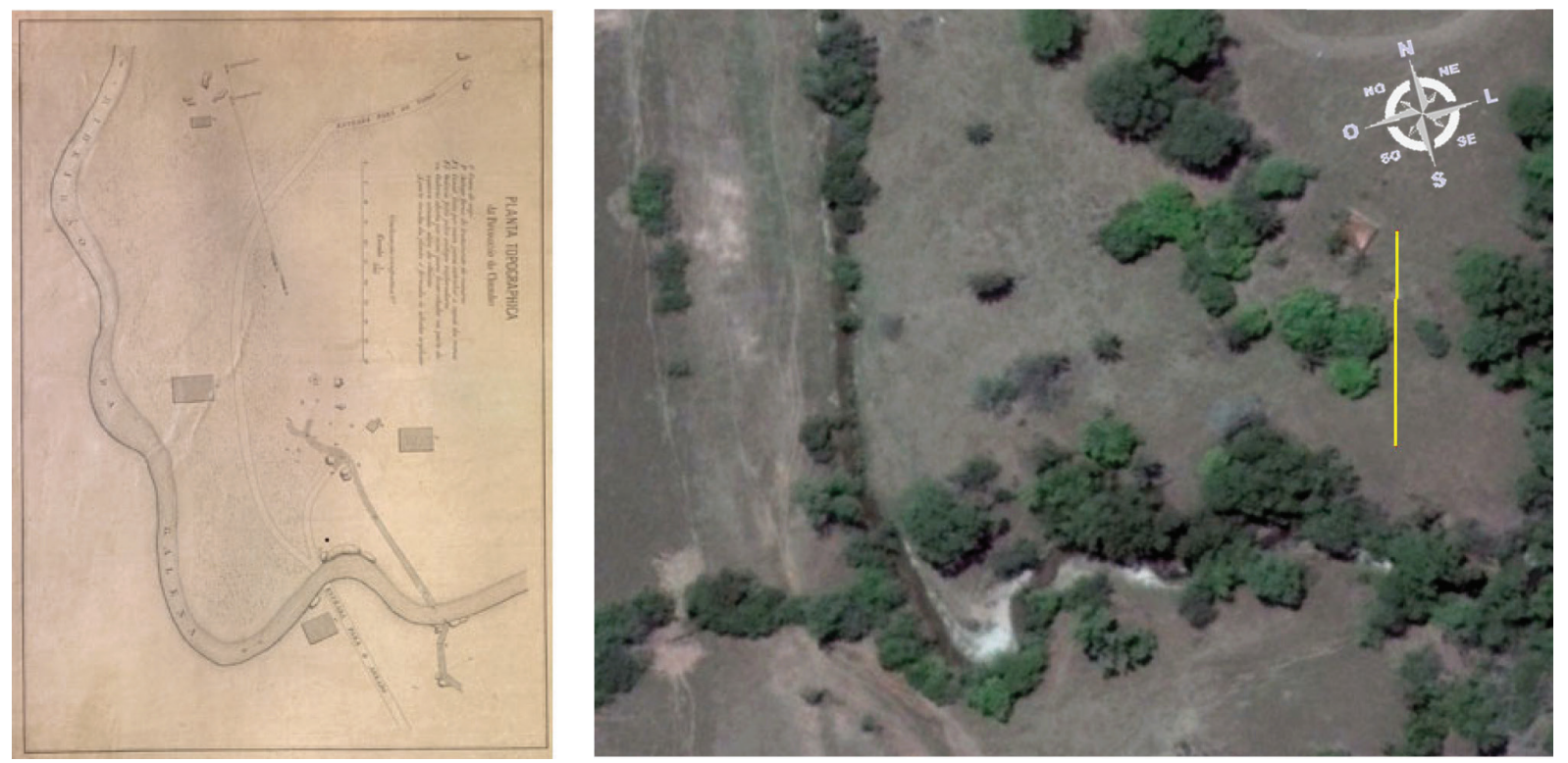

Figura 4. Mapa de F. P. Oliveira comparado a imagem de satélite que indica a posição da mina de galena (o traço amarelo na segunda imagem é uma escala de $50 \mathrm{~m}$ semelhante à usada por Oliveira) 

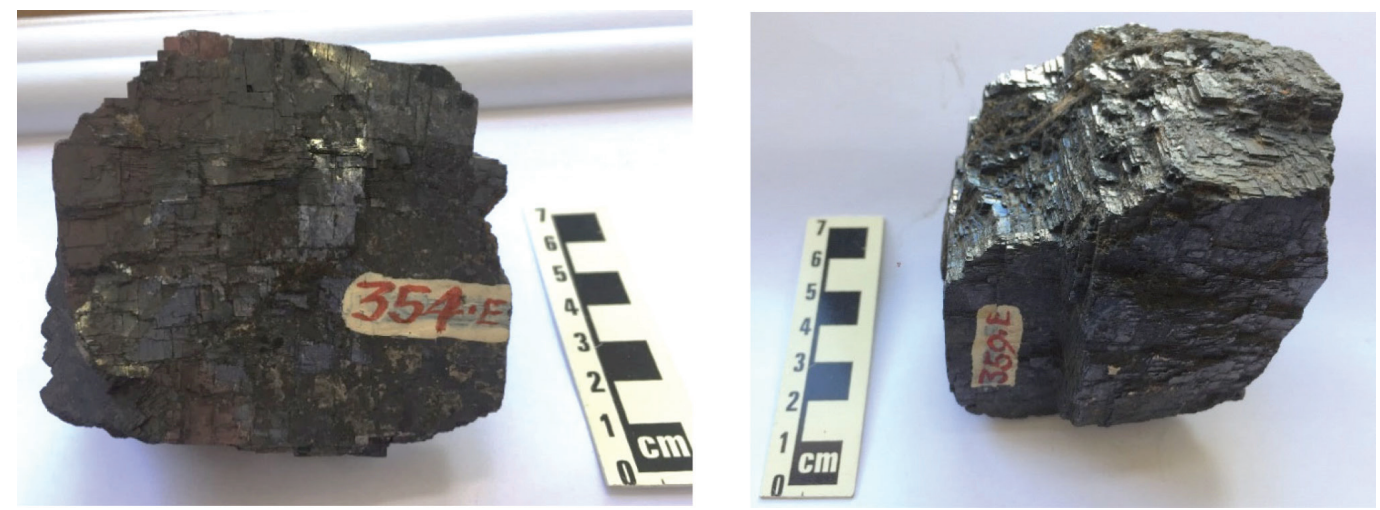

Figura 5. Amostras minerais de galena da Coleção Mineral de Geologia Econômica do Museu Nacional do Rio de Janeiro

Da mesma forma, o interesse pela obtenção de prata pela copelação do chumbo deve ter sido um dos motores da extração efetuada por Eschwege, que obteve valores bem acima da média das análises realizadas $(0,34 \%)$. No entanto, vale destacar ainda a provável pureza das amostras ensaiadas, que podiam apresentar variação quanto a sua composição (em chumbo ou em prata) que, como Oliveira demonstra em seus dois ensaios, pode ser alterada pela sua extração em diferentes pontos da cava da mina.

A visita de campo não possibilitou encontrar o veeiro de galena no sítio descrito por estar muito profundo e soterrado por ação do prolongado tempo de abandono. No entanto, no Museu Nacional da UFRJ o livro de tombos da "Coleção Mineral de Geologia Econômica" indica a existência de duas amostras minerais de galena provenientes "do Abaeté" cadastradas com os códigos 354-E e 359-E. Apesar de não ser possível a identificação do coletor ou mesmo a data da aquisição das amostras, as amostras devem ser parte do mineral analisado e extraído durante as missões de algum dos naturalistas envolvidos com aquela mina. Estas amostras estão mostradas na Figura 5.

Para comprovação do teor de prata foram cedidas pelo Museu Nacional do Rio de Janeiro pequenas alíquotas dos minerais mostrados. É irônico e triste que estas amostras foram fotografadas no Museu Nacional pouco antes da tragédia que vitimou o museu no início de setembro de 2018. Com as alíquotas realizaram-se análises em microscópio eletrônico de varredura (JEOL, modelo JSM - 6360LV) com detector de elétrons secundários para alto vácuo, detector de elétrons retro-espalhados para alto e baixo vácuo, detector de EDS (espectrômetro de raio-X de energia dispersiva) e detector de EBSD (difração de elétrons retro-espalhados), pertencente ao Centro de Microscopia da UFMG.

Utilizaram-se padrões de galena, prata, ferro e ouro para calibração do equipamento e a amostra foi bombardeada em um grid linear. Imagens de elétrons retro-espalhados e as composições químicas dos cristais de galena obtidas indicam que a amostra 354-E apresenta pequenas incrustações de material mais rico em oxigênio (provavelmente cerussita, um carbonato de chumbo) mas que no geral, assim como a amostra 359-E, encontra-se de forma bastante homogênea com cristais de hábito cúbico.

A análise quantitativa dos elementos químicos indica teores muito baixos para ferro e ouro na amostra, conforme haviam sido sugeridos por Jean Monlevade, e indica proporções em percentagem de massa para a relação chumbo-enxofre bem próximas ao cálculo estequiométrico para o sulfeto de chumbo - 87,7\% de $\mathrm{Pb}$ e $13,6 \%$ de S (Tabela 3).

Os teores de prata apresentados estão dentro do limite de detecção do método e abaixo (cerca da metade) do previsto pelos antigos cientistas (média igual a 0,19\% na Tabela 1). Além de considerar que as análises de Vieira Couto, Eschwege, Monlevade e P. Oliveira
Tabela 3. Análise por microscopia eletrônica das amostras de galena do Abaeté do Museu Nacional da UFRJ

\begin{tabular}{ccccccc}
\hline & $\mathrm{Pb}(\%)$ & $\mathrm{S}(\%)$ & $\mathrm{Ag}(\%)$ & $\mathrm{Au}(\%)$ & $\mathrm{Fe}(\%)$ & Total $(\%)$ \\
\hline Amostra 354-E & 85,63 & 13,35 & 0,10 & 0,01 & 0,02 & 98,51 \\
Amostra 359-E & 85,57 & 13,36 & 0,09 & 0,00 & 0,01 & 99,03 \\
\hline
\end{tabular}

pudessem estar superestimadas, deve-se considerar ainda que a amostra analisada pela técnica moderna pode não ser representativa daquela que era minerada no veio de galena ou ainda que a prata que era obtida no processo final ainda contivesse uma pequena parcela de chumbo, o que aumentaria o rendimento do processo.

\section{CONSIDERAÇÕES FINAIS}

São surpreendentes as narrativas da conquista dos sertões de Minas Gerais na busca por riquezas minerais em diferentes regiões da província. Imaginar as situações oferecidas por uma natureza selvagem e também o gosto pelas descobertas pode fazer acreditar que, mesmo inadvertidamente, os homens envolvidos nos fatos narrados nos documentos históricos estavam desenvolvendo algum tipo de pesquisa pré-científica.

Fato é que mesmo nas incursões mais marginais, riquezas em forma de metais e pedras preciosas desenvolveram a colonização e povoamento de todos os cantos da província. Narrando seus achados, muitas vezes de forma fantasiosa e exagerada, os sertanistas conseguiram que o governo incentivasse e financiasse a investigação por rentabilidades que poderiam ser alternativas econômicas, pois no século XIX não mais se encontravam ouro e diamantes em abundância na região central da província. Assim se deram as explorações dos sertões desconhecidos por especialistas (naturalistas, mineralogistas, químicos e engenheiros.

José Vieira Couto, mesmo que aparentemente limitado em sua capacidade de aplicação de conhecimentos teóricos e que ainda encontrava grandes dificuldades em suas análises químicas, mais uma vez se mostrou um grande cientista de campo, que mesmo ante obstáculos impostos pela natureza teria conhecido grande parte do território de Minas Gerais, antes mesmo das descrições e narrativas feitas pelos naturalistas europeus.

Dando, além de descrição do veeiro de galena, apontamentos de sua riqueza em chumbo, Couto disponibilizou informações suficientes para aguçar o interesse pela riqueza pelo metal em influentes políticos de além-mar que mais tarde incentivariam sua extração e benefício, mesmo sabendo das dificuldades de um negócio tão distante de centros urbanos e de um mercado acessível.

Coube a um engenheiro de carreira, o alemão Barão de Eschwege, que já demonstrara seu conhecimento e aplicação em Portugal, a 
continuidade nas explorações do sertão do Abaeté e ainda a implantação da Real Fábrica de Galena. Eschwege, não tendo que enfrentar apenas problemas de causa natural ou humana, teve ainda que votar atenção ao cenário político da capitania que parecia ou não enxergar vantagens ou simplesmente se opor às investidas do engenheiro europeu. A concorrência deste empreendimento com suas demais fábricas e ainda com os serviços que devia prestar à Junta Administrativa de Minas Gerais e do Reino devem ter sido prerrogativas para o abandono da mina de onde já tinha explorado dezenas de toneladas do minério, sem o sucesso da sua conversão a chumbo ou prata. As cartas e narrativas de Eschwege ainda levam a crer que uma imensa oposição se havia tramado contra ele; no entanto, aqui não podemos deixar de apontar que seus biógrafos e tradutores sempre concordam que o Barão, além de ser arrogante, desmerecia o trabalho alheio em que não estivesse envolvido. ${ }^{64}$

Ficaria então a cargo do despretensioso Monlevade conseguir a redução da galena a chumbo e sua copelação que, apesar de ser feita a um custo baixo em serviços e aparelhamento necessários, deve ter envolvido enormes valores no transporte de todo o chumbo vertido nos fornos que construiu no sertão.

Monlevade não deixou documentação suficiente como seus antecessores, mas demonstrou ainda desenvoltura, praticidade e rapidez em sua ação junto ao já implantado Império brasileiro tanto na ação descrita quanto na implantação da metalurgia moderna no estado.

Na história de quase um século da mineração e metalurgia do chumbo que teve seu primeiro capítulo em Minas Gerais, a busca pela implementação empresarial da extração do chumbo em Abaeté teve nas tentativas de Francisco de Paula Oliveira e Chrispiniano Tavares sua última chance de alcances financeiros reais. Oliveira deixou, da mesma forma que Couto e Eschwege, uma imensa contribuição científica e historiográfica que foi importante para o estabelecimento em Abaeté das primeiras fábricas do oeste mineiro.

\section{REFERÊNCIAS}

1. Burmeister, H.; Viagem ao Brasil através das províncias do Rio de Janeiro e Minas Gerais, Martins: São Paulo, 1952, p. 224.

2. Spix, J.; Martius, C. F.; Viagem pelo Brasil: 1817-1820, Vol. II., Ed. Itatiaia: Belo Horizonte, 1981, p. 123

3. Mawe, J.; Travels in the interior of Brazil, particularly in the gold and Diamonds districts of the country, Longman, Hurst, Rees, Orme, and Brown, Paternoster-Row: London, 1812, pp. 242-243.

4. O diamante do Abaeté, com 135 quilates (cerca de $27 \mathrm{~g}$ ), encontra-se ainda hoje em forma bruta e faz parte do tesouro real conservado no Palácio Nacional da Ajuda, em Lisboa.

5. Arquivo Histórico Ultramarino - AHU, CX. 128, doc. 20, 1788.

6. Filgueiras, C. A. L.; Origens da Química no Brasil, Editora da Unicamp/ SBQ: Campinas, 2015, pp. 229-235.

7. Gomes, F. M.; História da Siderurgia no Brasil, Itatiaia/EdUSP: Belo Horizonte/São Paulo, 1983, p. 71.

8. Idem, ibidem.

9. Couto, J. V.; Rev. Inst. Hist. Geogr. Bras 1848, 11, 289.

10. Couto, J. V.; Memória sobre as minas da Capitania de Minas Gerais, suas descrições, ensaios e domicílio próprios; à maneira de itinerário com um apêndice sobre a nova Lorena Diamantina, sua descrição, suas produções mineralógicas, e utilidades, que deste país possam resultar ao Estado, escrito em 1801, Tipografia Universal de Laemmert: Rio de Janeiro, 1842.

11. Couto, J. V.; Revista do Arquivo Público Mineiro 1905, 55.

12. Arquivo Histórico Ultramarino - AHU; Miranda C. L.1 - Coleção Cartográfica e Iconográfica Manuscrita do Arquivo Histórico Ultramarino. Carta ms.: color., desenho a nanquim; 40,3 x 32,6 cm em folha 45,1 x 35,1 cm, Cód. 2016-10-06T14:49:54Z, 1801.
13. Arquivo Histórico Ultramarino - AHU; Vilas Boas - Coleção Cartográfica e Iconográfica Manuscrita do Arquivo Histórico Ultramarino 1 carta ms.: color, desenho a nanquim; 40,3 x 32,6 cm em folha 45,1 x 35,7 cm. Cód. 2016-10-06T17:24:38Z, 1802.

14. Arquivo Histórico Ultramarino - AHU; CX. 154, doc. 97, 19/11/1800, pp. 1-3.

15. Couto, J. V.; Memória sobre as minas da Capitania de Minas Gerais..., Eduardo e Henrique Laemmert: Rio de Janeiro, 1842, p. 53.

16. Idem, p. 70.

17. Dardenne, M. A.; Schobbenhaus, C.; Metalogênese do Brasil, Editora UnB: Brasília, 2001, p. 194.

18. Bonev, I. K.; Mineral Deposita 1977, 12, 6.

19. Mello, S. L. M.; Quental, S. H. A. J.; Brazilian Journal of Geophysics 2000, 18, 3.

20. Buschele, B. N.; Palmeiro, J. K.; Sade, Y. B.; Melo, V. F.; Andrade, M. G.; Batista, A. H.; Rev. Bras. Ciênc. Solo 2010, 34, 1865.

21. Protocolo de vigilância e atenção à saúde da população exposta ao chumbo, cádmio, cobre e zinco em Santo Amaro, Bahia, Ministério da Saúde: Brasília, 2010, p. 13.

22. Couto, J. V.; Memória sobre as minas da Capitania de Minas Gerais..., Eduardo e Henrique Laemmert: Rio de Janeiro, 1842, p. 74.

23. Biblioteca Nacional - BN; Cód. BN, 14.4.22 - 1801.

24. Couto, J. V.; Memória sobre as minas da Capitania de Minas Gerais..., Eduardo e Henrique Laemmert: Rio de Janeiro, 1842, p. 123.

25. Idem, 158

26. Silva, C. P.; O desvendar do grande livro da natureza: um estudo da obra do mineralogista José Vieira Couto, 1798-1805, Annablume: São Paulo, 2002, p. 146.

27. Arquivo Histórico Ultramarino - AHU; CX. 182, doc. 53, 2/12/1806, p. 1.

28. Idem, p. 2.

29. Sommer, F.; Guilherme Luis, Barão de Eschwege, Edições Melhoramentos: São Paulo, 1952, p. 21.

30. Eschwege, W. L.; Brasil, Novo Mundo, vol. 1, Centro de Estudos Históricos e Culturais, Fundação João Pinheiro: Belo Horizonte. 1979, pp. 62.

31. Eschwege, W. L.; Pluto Brasiliensis, Vol. 2. Editora Itatiaia: Belo Horizonte. 1979.

32. Arquivo Histórico Ultramarino - AHU; CX. 111, doc. 87, cód. 189. sd.

33. Eschwege, W. L.; Pluto Brasiliensis..., p. 170.

34. "Mina", como se referem tais antigos autores, trata-se na verdade de mineral ou minério.

35. Arquivo Distrital de Braga - ADB, Universidade do Minho; Cód. PT/ UM-ADB/ FAM/FAA-AAA/000623, $1811 \mathrm{a}$.

36. Arquivo Distrital de Braga - ADB, Universidade do Minho; Cód. PT/ UM-ADB/ FAM/FAA-AAA/000624, $1811 \mathrm{~b}$

37. Arquivo Distrital de Braga - ADB, Universidade do Minho; Cód. PT/ UM-ADB/FAM/FAA-AAA/000628, 1812a.

38. Arquivo Distrital de Braga - ADB, Universidade do Minho; Cód. PT/ UM-ADB/FAM/FAA-AAA/000629, 1812 b.

39. Na tradução do Pluto Brasiliensis de 1979, por D. M. Murta, publicada em coedição por Itatiaia e EDUSP menciona-se o uso de "dinamite", o que é absurdo, uma vez que a dinamite só seria inventada por Alfred Nobel em 1867. O explosivo usual na época era a pólvora.

40. Eschwege, W. L.; Pluto Brasiliensis..., p. 181.

41. Revista do Arquivo Público Mineiro - RAPM. Imprensa Oficial de Minas Gerais: Ouro Preto, 1911, pág. 480.

42. Eschwege, W. L.; Pluto Brasiliensis..., p. 183.

43. Araujo, L. A.; Lorenzi, M.; O Brasil de ferro e aço: comédias e tragédias da mineração e siderurgia Brasileira, Editora Arte e Ciência: Rio de Janeiro, 2005, p. 48.

44. Passos, J. M. N.; Monlevade, vida e obra, Minas Gráfica: Belo Horizonte, sd, p. 25. 
45. Correio Official, n. 143, vol. $2^{\circ}, 19$ de dezembro de 1839

46. Revista do Arquivo Público Mineiro - RAPM; Imprensa Oficial de Minas Gerais: Ouro Preto, 1898, pp. 757-758.

47. Cadinho feito de pó de Carvão e azeite.

48. Abelha do Itacolumy, nº 87 de 30 de Julho de 1824, p. 346.

49. Revista do Arquivo Público Mineiro - RAPM; Imprensa Oficial de Minas Gerais: Ouro Preto, 1898, pp. 757-758.

50. Revista do Arquivo Público Mineiro - RAPM; Imprensa Oficial de Minas Gerais: Ouro Preto, 1898, p. 749.

51. O Universal, no. 3, de 19 de abril de 1828.

52. BNDigital, Coleção Casa dos Contos, cód. 354.8151, Manuscrito, 1829.

53. Annaes do Parlamento Brasileiro. Segundo ano da terceira Legislatura, tomo segundo. Typographia de Viuva Pinto \& Filho, Rio de Janeiro, 1887. Págs. 95 e 96

54. Lemos, P. Em A história da Escola de Minas; Lemos, P., org.; Editora Graphar: Ouro Preto, 2012, p. 279.
55. Silva, C. B.; Revista da Escola de Minas de Ouro Preto 2014, 67, 319.

56. Santana, J. C. B.; Estudos Avançados, 1996, 10, 317 (Atas da Congregação da Escola Politécnica de São Paulo de 1896).

57. Lopes, M. M.; O Brasil descobre a pesquisa científica. Os museus e as ciências naturais no século XIX, Hucitec: São Paulo, 1997, p. 170.

58. Oliveira, F. P.; Annaes da Escola de Minas de Ouro Preto, 1881.

59. Oliveira, F. P.; BN - Cartografia Histórica, ARC.008,10,025, 1879.

60. Oliveira, F. P.; Annaes da Escola de Minas de Ouro Preto, 1881

61. O Liberal Mineiro, no. 136, ano V. Ouro Preto, 18 de outubro de 1882.

62. Tavares, C.; Revista de Engenharia 1883, 1, 225.

63. Gorceix, C. Em D. Pedro II e Gorceix: a fundação da Escola de Minas de Ouro Preto, Lima, M. R., ed.; Fundação Gorceix: Ouro Preto, 1977, p. 143-235.

64. De acordo com o proposto em algumas notas de rodapé do tradutor D. M. Murta in: Eschwege, W. L. Pluto Brasiliensis... pp. 291-294. 